\title{
Platelet-Activating Factor Acetylhydrolase
}

National Cancer Institute

\section{Source}

National Cancer Institute. Platelet-Activating Factor Acetylhydrolase. NCI Thesaurus. Code C122066.

Platelet-activating factor acetylhydrolase (441 aa, $\sim 50 \mathrm{kDa}$ ) is encoded by the human PLA2G7 gene. This protein is involved in platelet-activating factor metabolism. 